\title{
COVETOUSNESS AND DESIRE: THE TENTH COMMANDMENT IN AFRICA
}

\author{
Lisel H Kruger Joubert \\ Department of Old and New Testament \\ University of Stellenbosch
}

\begin{abstract}
This article deals with a central question regarding the interpretation of the tenth commandment, namely "do the two verbs that are translated with covet/desire in the tenth commandment refer to a solely mental attitude or do they necessarily imply action to make the object of desire one's own?" The Decalogue forms part of the relationship between God and Israel where certain values regarding life and harmony in the covenant community is promoted. The proposal of this article is that desire as a mental attitude is the theme of this commandment because it already leads to disharmony in a society even without action to attain the object of one's desire. The same mode of thought can be recognised in African cultures. In reading proverbs from Africa no clear indication is found that they relate to both coveting and any actions resulting from coveting, as with the tenth commandment. The proverbs warn against desire or coveting as mental activities per se.
\end{abstract}

"Be patient a burning desire is not a pain"

\section{Introduction}

This article forms part of a bigger research initiative regarding African perspectives on the Decalogue. It also needs to be appreciated as part of the more intensive field of Decalogue research. Taking this into account I propose to work within the boundaries elicited by the specific questions that the history of research on the tenth commandment has raised.

The two versions of the tenth commandment read as follows:

Exodus 20:1: You shall not covet your neighbour's house, you shall not covet your neighbour's wife, or male or female slave, or ox, or donkey, or anything that belongs to your neighbour. (NRSV)

Deuteronomy 5:21: Neither shall you covet your neighbour's wife, neither shall you desire your neighbour's house, or field, or male or female slave, or ox, or donkey or anything that belongs to your neighbour. (NRSV)

The difference between the Exodus and Deuteronomic version have been noted by scholars and lead to the formulation of quite a few hypotheses. The differences are twofold: first regarding the Hebrew verbs in the text: In Exodus 20:1 we find only the verb hmd, in contrast we find in Deuteronomy 5: 21 first the word hmd and then ' $w h$. The other difference between these two texts is that the wife is placed in front of all the other possessions in Deuteronomy.

This article is however not concerned with questions relating to these differences or the questions regarding the dating of these two versions. The scopus of interest is rather the two verbs that are used. The questions that will be focussed on are:

- How do we understand these two verbs? 
- Does these two verbs refer to a mental attitude or does it necessarily imply an action in order to make the object of desire one's own?

- How do we understand the objects that may not be coveted?

\section{Comparing the two verbs}

Let us first look at the meaning of these two verbs. Hmd and ' $w h$ can be understood as synonyms. They also often appear in parallelism, for example Genesis 3:6. The slight difference in nuance is closely related to the context in which the verbs are found. It can be stated that the word " $w h$ expresses the desire that arises from an inner human need and the word $h m d$ refers to desire that comes from seeing something beautiful. The word $h m d$ does not refer to the "desire" that is inherently human (concupiscence) but to the act of desire which is generated by the emotion, which follows a visual expression. The word hmd therefore usually refers to behaviour, which is the result of a visual perception. These words are found in different contexts in the Old Testament and can have a positive, neutral or negative meaning. In the tenth commandment it is interpreted as negative.

\section{Mental attitude or action?}

The second question dealing with the possibility that this commandment forbids only the mental attitude of desire, motivated me to look at this commandment from a wisdom perspective. In this article I work with the hypothesis that the wisdom gathered in the closely knit community of family and clan of early Israel formed the context for the origin of the Decalogue.

Within this perspective the tenth commandment appears as an exception in the study of the Decalogue. On the one hand I can relate to research on the eight commandment Thou shall not steal, but on the other hand the questions raised by the tenth commandment gives it a different wisdom perspective, namely the possibility of forbidding certain mental activities. This commandment presupposes questions regarding the acceptability of mere desire.

These perspectives underline the fact that the Decalogue is not merely an exponent of criminal law but the product of a deeper relationship between God and Israel. A relationship that asks for responsible behaviour from both the individual and the group. Harrelson (1980:149) asks quite rightly: "Is there a reason to suppose that a law dealing with the attitudes or emotions, rather than the actual deeds, should be a too subtle or too refined religious notion for ancient Israel?" This is a legitimate question and will be referred to again later in the article.

A small teaser from the Book of Job, as the epitome of wisdom, may advance the argument: I have made a covenant with my eyes how then could I look upon a virgin. What would be my portion from God above and my heritage from the Almighty on high? Does not calamity befall the unrighteous and disaster the works of iniquity? Does he not see my ways and number all my steps. If I walked with falsehood and my foot has hurried to deceit let me be weighed on a just balance and let God know my integrity (Job 31: 1-4 NSRV)

\section{The relationship between God and Israel}

The covenant ideology understood the Decalogue as a sign of the relationship between God and Israel. Ben-Chorin (1979:36) identifies the idealistic and typical character of the Decalogue. It signifies that Israel wants to accept the will of God and that blessing and punishment will flow from their honouring of these commandments. The commandments 
are a sign of a relationship between God and Israel (formalised in the covenant) and the honouring of these commandments is the responsibility of the group as well as the individual.

Jackson (1975:12) saw the means of the enforcement of the Decalogue as the power of God to punish under the terms by which Israel accepted the law. The duty of the Israelites to uphold the relationship was strongly connected with the idea: that you may live. It reflects God's demand on the individual and society. These commandments originated for the sake of the community, especially the fifth, seventh, eight and tenth commandments aim to protect the community externally and internally (Wright 1979:102). The Israelite community had to protect and conserve the social units that were the foundation of this community because the powers that endanger the family endanger the relationship of the people to God.

Wright (1979:108) also identifies the crucial link between ownership in the society and the sharing in the blessings of God. Wittenberg (1978:12) interprets the tenth commandment from a covenant and socio-economical perspective, he argues that this commandment implies that the property of the neighbour is under the protection of God. God is the guardian of those who cannot protect themselves. In a situation where the rights of these people are undermined by the desire of others, God himself becomes involved. When the commandments are ignored the shalom of the community are endangered.

The ethical norms that are at play in the Decalogue are born from a relationship between God and his people and an inner acceptance that a higher power is at play. They are not laws that are products of a mere criminal justice system. Ignoring these commandments can lead to the breakdown of a community and their relationship to the divine.

\section{Perspectives from African culture}

What new perspectives can we gain from African culture for the interpretation of the tenth commandment? My reading of African proverbs was a learning process and hopefully a step toward a better understanding of the different cultures with which I share this continent. I have picked perspectives from a wide cultural range for the purpose of this paper, although I do rightfully understand that the diversity of African people cannot be fully represented through my selected examples.

While acquainting myself with the world of African ethics and researching the topic of desire/covetousness in proverbs from African soil I recognised one central concept which is crucial to both the Old Testament laws and the motivation behind African morality/ethics and that is life.

Lumbala (1999: 43) motivates that moral law and covenant plays an important role in the life of the African people. Honest moral conduct is a source of happiness and creates harmony between human beings, the creator and the order of the universe. Harmony is a familiar word, it is one of the few meanings of shalom, a well known Old Testament concept.

African ethics is directed towards life. Lumbala (1999: 43) writes about the role of the Decalogue in African society and finds the African society is not unacquainted with the idea of a covenant. He sees the covenant concept as intrinsic to African society and the covenant receives its power of life from the vital communion between the members of a society. The power of life is always triumphant.

Over the years discussions regarding ethics and morality in Africa were dominated by an agreement regarding the strong anthropocentric character of this system. It was described as anthropocentric because of the focus of African ethics on the community, the 
fact that the members of a group share the obligation to contribute to the growth of the life of the whole community by their moral action (Bujo 1997:25). This also presupposes that any action that prevents the fulfilment of both common and individual life is seen as evil.

Bujo (1997:25) wants to refute the onesidedness of this perspective and concentrates on the inherent theocentric dimension of African ethics. He finds it hardly conceivable that the African, whose thinking is always set in a religious context, can have a morality without God. If one hurts ones own people one sins against God.

In reading some proverbs on desire a common motivation was recognised, namely the fact that desire/coveting is futile and leads to death. Therefore it cannot be for the good of society and does not promote the preservation of life.

The first proverb I want to share is one which originates from the Akan people in Ghana, which says: Pray for life and not for possessions. This proverb gives a clear insight into the priorities of this community. Life is seen as more important than possessions.

The futility of desire is seen in the following proverbs: The Lugbara people of Uganda believe: Covetousness helps no one. This means that in the end no good comes from coveting, you only hurt yourself, neighbour and community. Another says: The eye is satisfied, thus it is futile to covet because you never have enough and this conviction will always fill your mind.

Coveting is futile and can lead to death, this is motivated in these two examples: If you love money you die a premature death and the love of money brings forth all evil. The Yoruba of Nigeria believes: Covetousness is the father of disease.

Examining these proverbs it is clear that the objects of these desires are either money or women, for example: Beauty and money make fools of people (Oromo, Ethiopia). Here I want to address the objects that are forbidden to covet in the Decalogue. Two texts uses the same verbs for covet which we find in the Decalogue, namely hmd and ' $w h$ with beauty as the object of desire. The first is Psalm 45 where an imperative is directed at the new queen that her beauty must be desired by the king, the king as the beautiful and blessed one. The beauty of the women is used to highlight the beauty of the king, and desire ' $w h$ is interpreted as positive within the legitimate context of a marriage (Kruger 1998: 88).

In Proverbs 6 we have the opposite. Coveting is seen as negative $(h m d)$. The object of desire, the women of the other, can be seen as either a non-Israelite cultic goddess who could harm the honouring of Jahwe by Israel or as a flesh and blood seductress. Both of these interpretations can be viewed from the perspective of the sage who wants to perpetuate the covenant community. He warns against any person or cult that endangers the covenant foundations. Camp (1985:27) recognised the characterisation of this woman in Proverbs as an antithesis to wisdom. Camp (1985:268) also recognised the critical role the wife plays in the identity of the community- the wife defines the Israeliteness of her house. The desire awakened by this other woman can be detrimental to the community and the individual. Beauty and coveting are therefore seen as negative in this context.

Two African proverbs regarding beauty are as follows: Character not beauty (Igala, Benin kingdom), Beauty should not deceive you (Kagomo). These African proverbs regarding beauty do not necessarily entail the beauty of another person's wife but do warn that beauty is ambivalent and cannot always be trusted, a wisdom perspective shared with the Old Testament.

The few proverbs I have quoted give us a possible perspective from Africa on the commandments. I referred to Harrelson's question earlier in the article: Is the idea of the forbidding of a mental attitude too subtle for Israelite society? The same question can be asked with regard to the African ethical structure. I would like to extend an invitation that 
we will not be so presumptuous and patronising to think that only certain cultures can achieve a certain nuance and subtlety in both their wisdom and law. I argue that there exists no definite reason not to accept the possibility that the tenth commandment forbids a mental attitude. It rather indicates the acceptance of a responsibility towards God and the community.

Job 31 shows that a covenant can be made by an individual with God which entail set ethical rules regarding both thoughts and actions. In the above African proverbs I noted that not one explicitly denotes action which follows from desire. It does give a reason why coveting can be seen as dangerous, but it does not necessarily imply any action. Coveting in any way will be detrimental to a closely knit society where responsibility towards God and neighbour is a prerequisite for membership. In this article I choose for an interpretation of the tenth commandment which forbids the mental attitude of coveting that which belongs to someone else.

Bujo (1997:28) relates one example that underlines the above: in African ethics the individual is accountable for the undone deed that remains hidden in his/her heart, because the thoughts and actions can have an influence on the community. He claims that even before the coming of Christianity public courts were interested in the motivation and intention that lead to the deed, even the intention to kill was seen as punishable.

The Decalogue forbids the coveting of beauty (wife) and possessions (money) without a motif clause. Even without a motif clause I would like to raise the option/possibility that the wisdom tradition behind this prohibition includes a conviction that the coveting/desiring of that which belongs to your neighbour will in the end lead to disrespect for God and your neighbour. The inherent futility and mortal danger of coveting that which belongs to someone else is also recognised in African Proverbs. I hope that a door is opened for a new perspective on our own understanding of this commandment we most probably know by heart.

\section{BIBLIOGRAPHY}

Ben-Chorin, S 1979. Die Tafeln des Bundes. Das Zehnwort vom Sinai. Tübingen: JCB Mohr.

Bujo, B 1997. The ethical dimension of community. The African model and the dialogue between North and South. Paulines Publications Africa.

Camp, V 1985. Wisdom and the Feminine in the Book of Proverbs. Sheffield. JSOT Press.

Harrelson, W 1980. The ten commandments and human rights. Philadelphia: Fortress Press. Jackson, BS 1975. Essays in Jewish and Comparative Legal History. Leiden: EJ Brill.

Kruger, LH. "Die ambivalente aard van skoonheid en begeerte in die Ou Testament" In die Skriflig 32 (1998) 85-96.

Lumbala, FK 1999. "Exodus 20:1-17. An African Perspective", in Rerturn to Babel. Global perspectives on the Bible. Louisville: Westminster/John Knox, 43-48.

Wittenberg, G. "The tenth commandment in the Old Testament" JTSA 22 (1978) 3-17.

Wright, CJH. "The Israelite household and the Decalogue: The social background and significance of some commandments" Tyndale Bulletin 30 (1979) 101-124. 